\title{
Classroom Management Problems and Coping Strategies of Misurata Libyan Secondary School EFL Teachers
}

\author{
Sumaia Mohammed Abu Habil ${ }^{1}$ \\ Misurata University
}

\author{
Laila Muftah Abu Lifa \\ Misurata University
}

Received: 15-12- 2019 Accepted: 03-02-2020 Available Online: 06-02-2020

https://doi.org/10.36602/faj.2020.n15.04

\begin{abstract}
Classroom management $(\mathrm{CM})$ is one of the most pressing problems faced by Libyan Secondary School teachers in Misurata City. This study used mixed research design (quantitative and qualitative ) to find out the classroom management problems and coping strategies. The participants of the study were10 female Libyan teachers from Asma secondary school in Misurata. All of them were chosen randomly and they were asked to fill in the questionnaire. Also, two main teachers were observed in their class time. The analyses of data obtained from the questionnaire and observation indicated that there are two kinds of classroom problems faced by English Foreign Language Teachers (EFLT) mainly students' misbehavior in the class and academic problems of teaching large class sizes with mixed abilities, and seating arrangement. The findings showed that $100 \%$ of teachers were in agreement that the behavior problems can disrupt teaching and learning processes. On the other hand, all of teachers agree that large class size affects the quality of their teaching and impacts on monitoring / evaluation of lessons. Various coping strategies were also elicited to deal with each problem mentioned.
\end{abstract}

Keywords: classroom management, (behavior \& academic) problems, \& coping strategies.

abuhabilsumaia@gmail.com ${ }^{1}$

https://misuratau.edu.ly/journal/arts 
مشاكل إدارة الفصول الدراسية واستراتيجيات التكيف لمعلمي مرحلة التعليم الثانوي بمدينة مصراتة الليبية

$$
\text { ليلي مفتاح أبوليفة }
$$

سمية محمد أبوحبيل

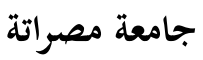

\section{ملخص البحث}

إدارة الفصول الدراسية (CM) هي واحدة من المشاكل الأكثر إلحاحا التي يواجها معلمو المدارس الثانوية الليبية في مدينة مصراتة. استخدمت هذه الدراسة تصميم البحوث المختلطة (الكمية والنوعية) لمعرفة مشاكل إدارة الفصول الدراسية لمائه

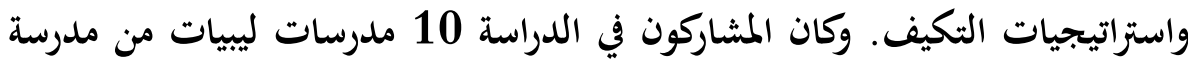
أسماء الثانوية في مصراتة. وقد تم اختيارهم جميعاً عشوائياً وطُلب منهم مل مل التهات الاستبيان.

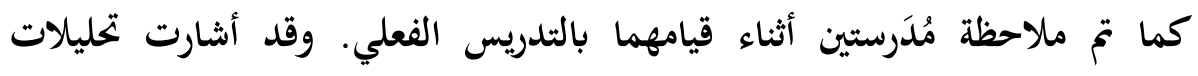

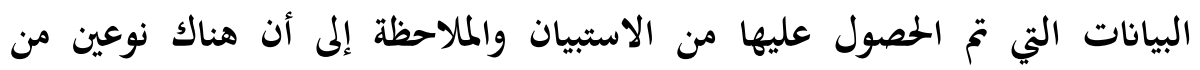

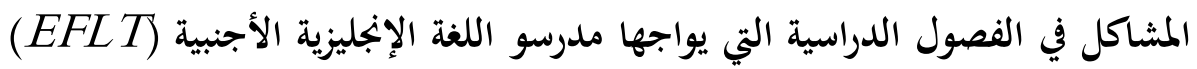

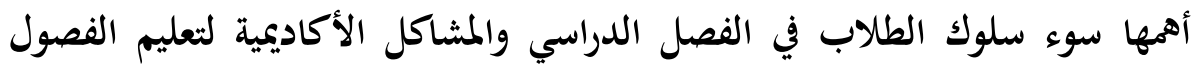

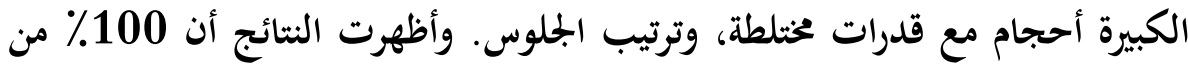
المعلمين كانوا متفقين على أن مشاكل السلوك يمكن أن تعطل عمليات التدريس

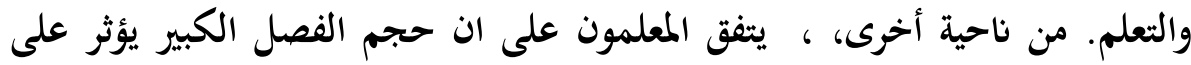

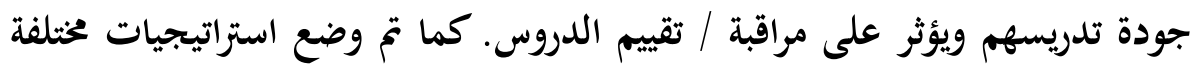
للتكيف والتعامل مع كل مشكلة مذكورة. 


\section{Introduction}

According to Brophy (2006)," Classroom management refers to action taken to create and maintain a learning environment conducive to successful instruction ( arranging the physical environment, establishing rules and procedures, maintaining students' attention to lesson and engagement in activities)" (p. 17). Classroom management is a key element to establish a successful learning environment in any classroom. An effective classroom management plan creates a positive learning environment. In addition, classroom management is affected by the characteristics of the students and their behavior.

Students' behavior is influenced by their age, academic abilities, goals, interests, and home backgrounds. Altinel (2006) suggests that, students exhibit tendencies of aggression, rowdiness, making noise or being excessively quiet. Some students are also low to comprehend while others constantly crave attention and need more follow up to grasp what is taught. Therefore, a teacher ought to have good classroom management skills to contain the students and their rowdy behaviors. These skills ensure that teachers are able to contain the different personalities and capacities of students in their care.

Therefore, coping strategies help teachers in establishing routines for students for example doing group or pair activities. Rules provide sense of regularity and organization for students and teachers. According to Kaya and Donmez (2009), classroom rules contribute towards the creation of productive learning environment. Hence, rules should be clear, reasonable and consistent. Moreover, effective teachers engage students in a variety of challenging and useful activities. This develops sense of cooperation among the students. According to Santrock (2006), teachers must be ready to attend to students' individual learning needs. For this the teacher can actively monitor the teaching-learning process by creating an engaging environment. Hence, teachers can actively monitor students by 
watching them closely, giving feedback to correct undesirable behaviors and to praise for good behaviors .

\subsection{Statement of the problem}

Nowadays, teachers face two kinds of classroom management problems. First, behavioral issues, many teachers struggle immensely with behavior issues, even expert teachers can find themselves spending too much of their valuable class time dealing with behavior problem. Second, academic problems such as; large class is considered as a major factor and that can barrier the learning process. Teaching large class is often characterized by one-way communication, which promotes teacher-centered learning and offering students less opportunities to express or discuss their opinions in class. Also, as time is limited, teachers do not usually arrange any in-class activity. Therefore, there is no learning activity for students to evaluate the new concepts. In the learning environment of large classes, it is difficult for students to maintain their concentration in a long period. Furthermore, teachers generally do not receive any feedback from students in large classes, thus it is difficult for them to assess students' understanding. In addition, there are other academic problems that come across teachers in classes such as mixed abilities, and seating arrangement. So that this study will serve teachers to identify the behavioral and academic problems inside the classroom, in order to find solutions to decrease the effect of these problems on the level of teacher participation and student achievement.

\subsection{The aim of study}

The purpose of study is to help teachers manage classrooms more effectively, to find out the classroom management problems at Asma secondary school as perceived by teachers, and to find some appropriate strategies to address them.

\section{4The research questions}

The study aims to answer the following questions: 
1.What are the problems faced by Asma secondary school teachers in managing their English classes?

2. What kind of strategies should be work in English classes to enhance Asma secondary school in managing their problems?

\subsection{The definition of classroom management}

Classroom management $(\mathrm{CM})$ is the process of keeping a controlled environment in order to enhance learning. Prodromou (1992) states that, CM is defined as encompassing the decisions that teachers take to facilitate the learning process and to provide the students maximum opportunity for learning. Kayikci (2009) suggests that, the fruitful outcome of a well-prepared physical environment facilitates the learning and teaching process and fosters the class participation of students.

\subsection{Problems of classroom}

Classroom behavior problems affect the teaching and learning process as it influences teacher's ability and competence in handling the classroom environment. Basar (1999) explained in his study "Classroom management" that, all sorts of behaviors that discontinuing education are called as unwanted behaviors. Misbehaviors in the class obstruct the class atmosphere, the teaching process and prevent both students and teachers from achieving their aims and lead to the problems in time management. Moreover, Fields (1999) suggests that" failure to address misbehavior compromises the learning environment whereby academic activities are interrupted, curriculum content is not covered, teacher authority is undermined, and most importantly, there are decreased opportunities to learn" (pp.11-12). Classroom behavior problems are a principle source of stress for both new and experienced teachers. Indeed, these behavior problems affects learning and teaching process.

Furthermore, the large class is one of challenges facing English Foreign Language (EFL) teachers. Watson Todd (2006) maintains 
that, "it cannot be denied that teaching large class is a burden to teachers, especially new teachers as they may face many problems in their classes" (pp. 3-4). Sarwar (2001) suggests that a big class is very difficult for class management. He says "some teachers feel uncomfortable when they have to face hundreds of eyes in a big class. A large class is often noisy that affects its teaching process and neighboring classes" (p.158).

In addition, Al- Jarf (2006) claims that, "due to the size of the class, teachers do not have enough time to pay attention to all students and give every student a chance to speak and participate"(p. 24). However, When teaching large classes, EFL teachers usually encounter many difficulties that affect their teaching process.

As a part of classroom management, teachers face the question of how and where to seat their students. According to Trussell (2008), one important aspect of classroom management is the physical design of the classroom. A classroom is an adaptable and often a flexible setting for which teachers make an arrangement for the tables, chairs, and other materials in order to stimulate active involvement in the lessons. Baines et al. (2003) reports that, unfortunately, this aspect of classroom management is hardly addressed in teacher trainings, even though the physical design of the classroom has shown to be important for both the academic and social development of students. Therefore, according to Wannarka and Ruhl (2008) seating arrangements can increase on-task behavior and decrease off-task behavior. Classroom management is an important task for teachers and part of this task is their responsibility for the physical design of the classroom. In order to assess whether teachers make effective seating arrangements for students' social and academic development .

The mixed-ability class is also one of challenges facing teaching instructors today. Ansari (2013) describes a mixed-ability class as comprising of not only learners with various capacities but also those that have a broad range of preferences and learning styles. 
According to Lightbown and Spada (2006), there are many factors which may differ from one student to another such as their attitude, motivation, and self-discipline. This makes it difficult for the teachers to effectively plan for. A mixed-ability classroom consists of a group of students with differing levels of learning abilities, interest, and skills. EFL teachers have grown to identify this as one of the greatest aspects that invariably determines the level of teaching and understanding of what the students undergo in the long run.

\subsection{Coping strategies}

English Foreign Language (EFL) Teachers need to plan and decide on how to deal with behavior that is inappropriate in classroom. Geiger (2000) informs this about his study:

Communication between teachers and students minimizes the chances of misunderstanding. This will lead to less discipline problems in the classroom. For maintaining good discipline behaviors management is a necessary. Hence, teacher must show firmness, tenderness and gentleness to deal with students' misbehavior. (pp. 383-393)

Furthermore, Nayak and Rao (2008) suggest that teachers must make the students realize their own behaviors for wrong doings or right. This will develop in students the habit of self-discipline. Moreover, to deal with student misbehavior in the classroom, Kyriacou (1997) suggests that "preventing" rather than "curing" the bad behavior in the classroom by the skill of "vigilance plus action", in which vigilance involves the teacher monitoring the students' behavior and appropriateness of the learning activities, and action is what the teacher does to sustain students' academic engagement in the learning experience whenever it seems to have problem. In this way, the incident level of misbehavior can be avoided. The appropriate steps for dealing with student misbehavior in the classroom are: understand it completely, think about it carefully and deal with it intelligently. The quality of the teaching and learning progress can be assured when student misbehavior can be controlled effectively. 
There are many teaching strategies that teachers can use to cope with large classes. Harmer (2007) explained in his article "How to teach English" that, cutting a big class into small groups is a strategy recommended by most researchers and teachers who experienced in teaching large-size classes. According to Renaud, Tannenbaum and Stantial (2008) in order to avoid discipline problems in class, especially in large classes, teachers can select prestigious, oldest or more advanced students who can take responsibility for helping others, as group leaders, monitors, or teaching assistants. Also, Harmer (2007) suggests that, creating a friendly atmosphere while teaching a big class is one of the strategies most authors suggest teachers of large classes use. Strategies that English language teachers can use when faced with large class size include many practices and skills. In addition, teachers have to devise techniques for coping and ensure that their students benefit from participation in a large class.

There are also many ways to arrange a classroom. According to Wannarka and Ruhl (2008) "arrangement in small groups, U-shaped seatings, or a classroom with undivided, flexible arrangements. Some of these arrangements are more common than others, such as an arrangement in rows or small groups" (pp. 89-91). McCorskey and McVetta (1990) suggest that, a seating arrangement in rows may be chosen to improve information dissemination, whereas an arrangement in small groups may be chosen to promote student interactions. In addition, seating arrangements can have consequences for students' academic engagement and development. However, the nature of the task and consequently the type of desired behavior dictates the most effective type of seating arrangement.

In addition. there are several strategies that influence teachers in mixed-ability classes to think in a different way to help their students attain academic success. According to Tomlinson and McTighe (2006), the recommended strategy for addressing teaching in a diverse-classroom is differentiation. This strategy has grown in status becoming a recurring theme in classroom instructional strategies. 
Pedersen and Kronborg (2014) convey that, instructors can divide their students into various groups, incorporating different studentcentered methods to improve on their study and to motivate them to participate more in their preferred learning method. Some of the student-centered methods include; game competition, in class activities, and extra homework.

\subsection{The importance of effective classroom management}

Effective classroom management paves the way for the teacher to engage the students in learning. According to Emmer and Stough (2001), the ability of teachers to organize classrooms and manage the behavior of their students is critical to achieving positive educational outcomes. Although good behavior management does not guarantee effective instruction, it establishes the environmental context that makes good instruction possible. Reciprocally, highly effective instruction reduces, but does not eliminate classroom behavior problems. Siebert (2005) suggests that, "teachers insist that their preparation programs teach classroom organization and behavior management skills, but the indication is that such skills are not taught thoroughly or with adequate supervision in a real classroom context" (pp. 385-387). According to Espin and Yell (1994)," the absence of supervised experience and professional development in the critical competencies of classroom organization and behavior management significantly reduces the effectiveness of many teachers, especially new teachers" (pp. 154-155). In short, classroom management strategies help create an organized classroom environment that's conducive to teaching.

\subsection{Classroom rules and routines}

The use of rules is a powerful, preventive component of classroom organization and management plans. Kerr and Nelson (2002) tell that, rules establish the behavioral context of the classroom by specifying what behaviors are expected of students, what behaviors will be reinforced, and the consequences for inappropriate behavior 
(e.g., reteaching the behavioral expectation) suggest that, if rules are stated or worded positively to describe the expected behavior, rather than what not to do, behavior problem is more easily prevented. Martella, Nelson, \&Marchand-Martella (2003) recommend that, rules should be consistent with the school wide behavior plan. Smith and Lastleth (2002) point out four rules in classroom management. The first is "get them in" which means the way teachers start a meeting or a class. This rule consists of greeting, seating and starting. The second rule is "get them out" which means the way how teachers end a meeting or a class. This rule consists of concluding and dismissing. Finally, The third rule is "get on with it" which means the main part of the lesson the nature of its content and the manner of its presentation and the fourth rule is "get on with them" which means teachers develop good personal relationship with their students. According to Gallagher (1998), classroom rules contribute towards the creation of productive learning environment. Through rules, effective teachers engage students in a variety of challenging and useful activities. This develops sense of cooperation among the students.

\section{Methodology}

\subsection{Research design}

The study used mixed research: First, quantitative, this type of data can be used to construct graphs and tables of raw data (Creswell, 2015). Therefore, a questionnaire is a research instrument that consists a set of questions or other types of prompts that aims to collect useful information from a respondent (Creswell, 2015). Second, qualitative, qualitative research focuses on gathering of mainly verbal data rather than measurements. Gathered information is then analyzed in an interpretive and naturalistic manner. This means that qualitative researchers study things in their natural settings, attempting to make sense of, or interpret, phenomena in terms of the meanings people bring to them (Creswell, 2015). This research method used observation to gather data. 


\subsection{Participants and Settings}

The participant were 10 female English language teachers selected randomly. The data sources for this observation are from Asma high school and they were two female English language teachers.

\subsection{Data collection}

Classroom Management Questionnaire (CMQ) was used to collect data. It comprised of two parts: The first part is classroom management problems and the second part is the strategies. This questionnaire utilized a Two-points scale ranging between (agree and disagree).(see appendix A). The observation was also used to gather data, this observation refers to what student researcher sees taking place in the classroom based on how to teacher manage the class.

\subsection{Ethical consideration}

The researcher addressed important ethical issues during the research process. All the information collected from the principal of the school, and participants have been kept strictly confidential. The permission to undertake the study was sought from the school's principal in English and Arabic.

\section{Results}

\subsection{Results and Discussion of the classroom problems survey}

1- The behavior problems can disrupt the teaching and learning processes. The result presented that the whole of participants agreed that the behavior problems could disrupt the teaching and learning processes. Behavioral problems are a constant threat in education process. Disruptive behavior of one student or a small group of students usually impedes the progress of other students and create difficulties in educational process for those students and for teacher (McManus 1995, p. 5). In the other words, disruptive behavior by 
one student encourages other students to do the same, which hinders the teacher's authority and ability to control the class.

2- To deal with behavior problems have a dramatic impact on a teacher's job and take more time.

\begin{tabular}{|c|c|}
\hline Disagree \\
$10 \%$ \\
\\
$90 \%$ \\
\hline
\end{tabular}

\section{Figure (1)}

As illustrated $90 \%$ of the teachers agreed that to deal with behavior problems, have a great impact on their job and take more time, while $10 \%$ of participants disagree with this item. Student misbehavior in the classroom is a tough task to the teachers and it takes up teachers' considerable time to deal with it. However, it is important to manage class time effectively. Teachers need to find the right balance and good planning to manage the time. Therefore, teachers who are adept at time management efficiently can discipline the behavior of their students and provide opportunities for them to learn more effectively.

3- My students do not listen to me and they have lack of attention.

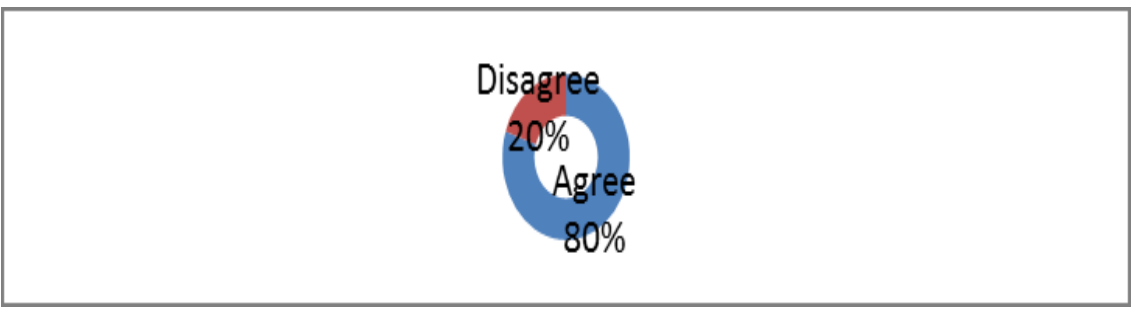

Figure (2)

The majority of teachers agree that their students do not listen to them and they have lack of attention. Whereas $20 \%$ of participants disagree with this view. Learning is likely to be greater and students' achievement would be better if their attention is directed towards the 
learning tasks and activities (Bloom, 1980). Learning begins with attention, but attention is not always easy to come by, especially in large classes. Indeed, teachers of big classes find it hard to keep all students' attention. However, teachers should know how to focus students' attention automatically. Therefore, they should work on developing ways of attracting inattentive students, whose attention should be diverted towards the lesson and basic activities during the class.

4- Large class size affects the quality of my teaching and influences useful monitoring / evaluation of lessons. All participants agreed that large size of classes is a prime impediment for the efficient English teaching. Also, large class size impacts on useful monitoring or evaluation of lessons. In larger classes, more time is needed for non-academic activities related to administrative and organizational procedures and to the management and control of discipline. Reductions in the quantity of learning opportunities constrain teachers from achieving the necessary pace, depth and breadth of curriculum coverage as class size increases (Pedders 2006, p. 224). In addition, teachers of big classes find that it is not easy to monitor students learning progress and giving them feedback.

5- My students can obtain the same level of learning in mixed ability class.

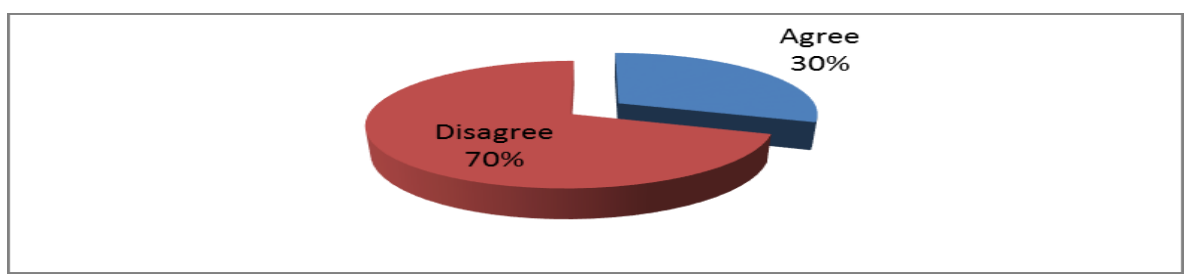

\section{Figure (3)}

The results indicate that the majority of participants $70 \%$ disagree that their students can obtain the same level of learning in mixed ability class. In contrast, $30 \%$ of teachers agree with this item. Mixed-ability classes mean classes where students differ greatly in 
ability, motivation for learning English, needs, interests, educational background, styles of learning, anxiety, experiences and so on (Ainslie, 1994). Mixed-ability classes generally refer to classes where learners have a broad range of levels in their achievement and learning. The students in these classes differ in strengths and weaknesses and have different approaches to learning

6- It is difficult to plan a lesson that fits all students with their different abilities. Half of participants involved in this survey agreed that EFL teachers encounter challenges to plan a lesson that fits all students with their different abilities while the other half of teachers disagree. Northcote ( 2006) reports that most classes are comprised of a large number of students, and it is the responsibility of the teacher to control the students and to deliver the lesson effectively.

7- The course books' activities do not suit the different levels of my students.

$\overbrace{\substack{\text { Disagree } \\ 90 \%}}^{\substack{\text { Agree } \\ 10 \%}}$

\section{Figure (4)}

The finding indicated that $90 \%$ of teachers disagree with this item because the course book can provide support for teachers to teach different levels of learners, moreover, it provides a variety of learning resources. On the other hand, 10\% of participants agreed that the course books' activities do not suit the different levels of students. Hutchinson and Torres (1994) argue that during periods of change, a course book can serve as a tool for supporting teachers and as an instrument of modifications and alterations. Most teachers consider course books to be valuable aids that offer useful material and support. Also, learners need course books to guide them towards the hard process of learning. A course book reinforces the teacher's 
work and offers material for further learning and revision. In brief, a course book provides teachers and learners with a structure of teaching and learning, methodological support and opportunities for revision and preparation (McGrath 2002). Moreover, it gives teachers relief as it reduces the heavy load of preparation, saves time and makes teaching and learning easier.

8- The classroom seating arrangement effects student to teacher interaction at class.

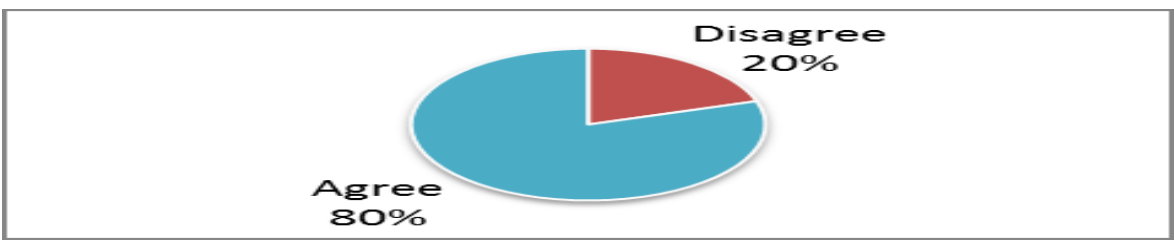

Figure (5)

The result obtained that $80 \%$ of EFL teachers agreed that seating arrangement effect student to teacher interaction at class but $20 \%$ of participants disagree with this point. Kaya and Burgess (2007) believed that seating arrangements in classrooms affect students' ontask behavior and social interaction. As part of classroom management, teachers face the question of how and where to seat their students. This is an important decision, as classroom-seating arrangements influence classroom climate, students' relationships with each other, and their interaction with teacher.

\subsection{Results and Discussion of the coping strategy survey}

1- Provide clear instruction and positive feedback to the students for following class rules. The majority of teachers $90 \%$ agreed about providing clear instruction and positive feedback to the students in order to follow class rules whereas $10 \%$ of the rest of teachers were in disagreement side. Giving Instruction has a direct effect on learning; a lesson or activity becomes chaotic and fails when students do not understand what they are supposed to do. Therefore, 
providing clear instructions to the students in classroom contribute to successful teaching and learning processes. Providing feedback means that giving students an explanation of what they are doing correctly and incorrectly.

2- Asking questions to get students' attention.

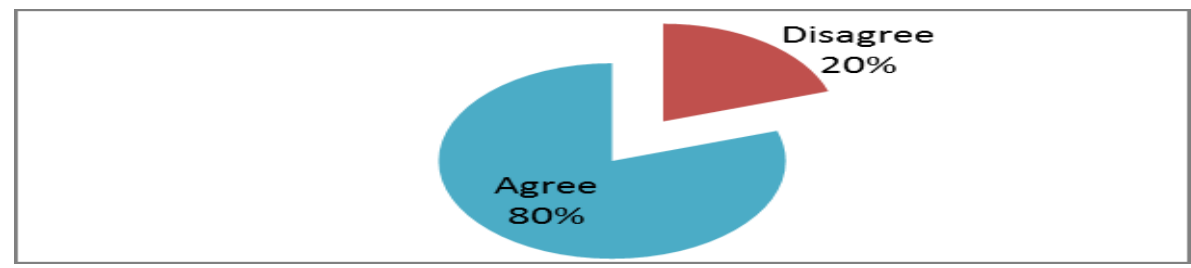

Figure (6)

The results revealed that $80 \%$ of participants agreed that asking questions is a better way to get students' attention. In contrast, the rest of voluntaries about $20 \%$ disagree with using this strategy. Asking questions to the students is an effective skill to get students' attention, and stimulate their interaction, thinking, and learning (Wood \& Carol, 2001). Learning and understanding are based on a good listening environment. Helping students develop good attention is the foundation of successful learning. Thus, asking questions to the students is the one of the effective strategies that can teachers use in the classroom to alleviate their students' lack of attention.

3- Using group / pair work activities.

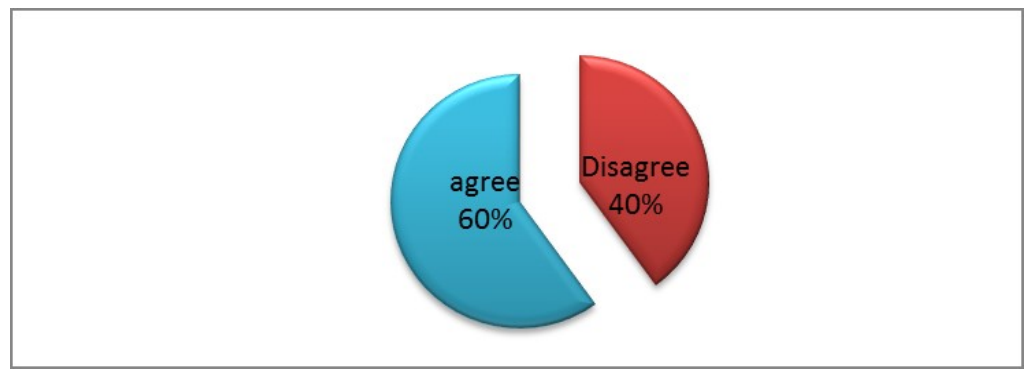

Figure (7) 
It is clear that $60 \%$ of teachers engaged in this study were completely in agreement with using group and pair work activities. Whereas $40 \%$ of them disagree with using this strategy. By implementing pair and group work teachers can improve classroom management process in large classes for creation of interaction opportunities between learners. Harmer (2001) pointed out that there is always a sense of achievement attached to pair and group work. When a pair or particular group finishes something successfully through collaborating with each other, there is a greater feeling of pride upon reaching a team goal.

4- Make use of eye contact, voice control, body language, and distance management to maintain large class's control. All the participants who were engaged in this study make use of eye contact, voice control, body language, and distance management to maintain large class's control. Gower and Walters (1983) claims that, the use of eyes and facial expressions are considered as having a disciplinary function in most of the sources and are reported as having many related functions, which help teachers in managing classrooms. According to Snyder (1998), the main uses of eye contact in the classroom are to show students and teachers; first, how to take notice. Second, to check that everyone is concentrating. Third, to indicate to a student that you want to talk to him or you want him to do something. Finally, to encourage contributions when one is trying to elicit ideas, to hold the attention of students, and to maintain control.

5- Creating a friendly atmosphere while teaching a big class. If a positive classroom atmosphere is created, students will learn better and engage more which means that it is one of the most effective and powerful strategies teachers can use to encourage student's learning. Creating a positive classroom atmosphere takes effort on the part of the teacher and students. By setting a positive example for students and using positive reinforcement to promote positive behavior, teachers can turn their classroom into a positive learning 
environment. It is important for teachers to create a relaxed, positive atmosphere in the classroom (Ainslie, 1994). Wright (2005) supports this theory, and he also claims that there is a strong connection between a good classroom atmosphere and having good behavior management. This will create a good learning situation.

6- Using lesson plans effectively and the teaching aids that fits all students with different abilities. It is implicit for English foreign language teachers to use lesson plans effectively and the teaching aids that fits all students with different abilities. Many teachers make efforts to make their students get the same amount of learning with using various techniques and materials. The use of visual aids in an EFL classroom has a beneficial effect on achieving the learning process. Kunari (2006) states that visual aids help teachers to enhance lesson plans and give students additional ways to process subject information.

7- When students' desks are arranged in rows, your students tend to stay on-task, focus, listen, and complete more work.

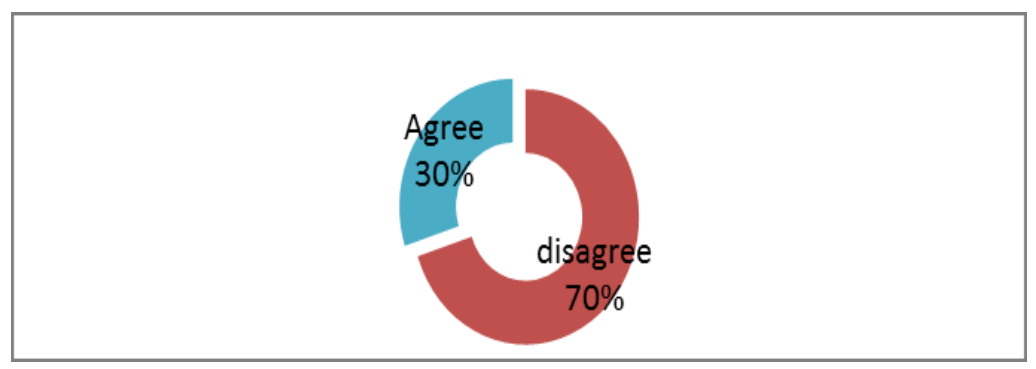

Figure (8)

$70 \%$ of the participants disagree that when students' desks are arranged in rows, the students tend to stay on-task, focus, listen, and complete more work. While $30 \%$ of participants agree with this point. According to Mineduc (2013) due to the large number of students in classes, the classroom organization mostly used at schools is orderly rows. This kind of organization does not promote students' interaction and participation in class. 


\subsection{Results and Discussion of the Observation}

Classroom observation focused on classroom management including problems facing teachers and their coping strategies that used inside classroom. The student researcher observed two teachers who faced two types of problems related to classroom management.

First, behavioral problems are one of the big issues encountered by Asma secondary school teachers. Among these kind of problems include the following: some students do not listen to the teacher and do not follow directions, while some students refuse to do any work or cooperate in any way. In addition, the student researcher noted that students were usually talking about topics unrelated to the lesson. The teachers used some strategies in classroom to address these problems. Educators must employ effective classroom management strategies to minimize failures in their classrooms (Shawer, 2010). Teachers used rules and system in class, and they used punishment when rules are broken. Furthermore, there were other strategies that were used by teachers such as rewarding the students, keeping silent, and changing students' seats. Conversely, both of them were not encouraging students to participate in an exercise or activity, and only teachers make classroom rules.

Second, teaching large classes with mixed abilities are considered one of most academic problems faced teachers in Asma high school. The student researcher recorded that teachers have difficulty in controlling big classes due to students' inattentiveness. Also, teachers cannot evaluate all students in large class. Having a large class prevented teachers from doing what they wanted to help learners make progress in developing educational process ( Locastro 2001, p. 494). To deal with this type of problems teachers were changing their teaching method or asking students questions about what they have said to pay attention, Moreover, teachers used group 
or pair work activity, they also used different teaching aids to support all levels of learners.

\section{Conclusion}

This study indicated that teachers manage misbehaviors by developing routines and they enhanced responsibility and provided positive feedback and specific praise to students who followed the rules. In addition, teachers used punishment when rules are broken and they did not share classroom rules with their students. Secondly, the study discovered that the teachers used teaching aids for teaching large classes with mixed abilities. The study further observed that teachers asked questions during class time to get students' attention. Also, it was noticed that the teachers created friendly environment in classroom. Furthermore, the study realized that the order of seats in rows did not encourage students' interaction and participation in class. Overall, these results give the teachers knowledge to manage disturbing behaviors and academic problems by improving positive classroom management practices.

\section{References}

Ainslie, S. (1994). Mixed Ability Teaching: Meeting Learners' needs. Network 3: Teaching Language to Adults. London: Centre for Information on Language Teaching and Research.

Al-Jarf, R. (2006). Large student enrollments in EFL programs: Challenges and consequences. Asian EFL Journal Quarterly, 8(4), 24.

Altinel, Z. (2006). Student misbehavior in EFL classes: teachers' and students' perspectives. (Unpublished MA Thesis). Çukurova University, Adana.

Ansari, M. S. (2013). Coping with the Problems of Mixed Ability Classes: A Study in the Context of Teaching English as SL/FL. International Journal of English: Literature, Language \& Skills. 
Baines, E., Blatchford, P., and Kutnick, P. (2003). Changes in grouping practices over primary and secondary school. International Journal of Educational Research, 39, 9.

Basar, H. (1999). Classroom management. [In Turkish: SÕnÕf yönetimi]. østanbul: National Education Ministry Publications.

Bloom, B. (1980). Human characteristics and school learning. New York: McGraw - Hill, 1980.

Brophy, J. (2006). History of Research on Classroom Management. In C. M. Evertson\& C. S.Weinstein (Eds.), Handbook of classroom management. Research, practice, and contemporary issues (p.17). Malwah, NJ: Lawrence Erlbaum Associates.

Creswell, J. (2015). Introduction to Social Research: Quantitative and Qualitative Approaches. London: Sage.

Emmer, E. T., and Stough, L. M. (2001). Classroom management: A critical part of educational psychology, with implications for teacher education. Educational Psychologist, 36(2), 103-112.

Espin, C. A., and Yell, M. L. (1994). Critical indicators of effective teaching for preservice teachers: Relationships between teaching behaviors and ratings of effectiveness. Teacher Education and Special Education, 17, 154-155.

Fields, B. (1999). The impact of class heterogeneity on students with learning disabilities. Australian Journal of Learning Disabilities, 4, 11-12.

Gallagher, J.D. (1998). Classroom assessment for teachers. Upper Saddle River, NJ. Merrill.

Geiger, B. (2000). Discipline in $K$ through 8 th grade classrooms. Education, $121 \quad$ (2), 383-393.Retrieved from http://findarticles.com/p/articles/mi_ga3673/is_2_121/ai_n288 $10256 /$.

Gower, R. and Walters, S. (1983). Teaching Practice Handbook. Oxford: Heinemann.

Harmer, J. (2001) The Practice of English Language Teaching. Harlow: Longman. 
Harmer, J. (2007). How to teach English, 2nd ed. UK, Pearson Longman.

Hutchinson, T. and Torres, E. (1994), The textbook as agent of change, ELT Journal 48.4:315-28.

Kaya, A., and Donmez, B. (2009). An evaluation of the classroom management approaches of the class teachers implementing constructivist learning approach. Procedia Social and Behavioral Sciences, 1, 575-576.

Kaya, N. and Burgess, B. (2007). Territoriality: seating preferences in different types of classroom arrangements. Environment and Behavior, 39, 859-876. doi: 10.1177/0013916506298798.

Kayikci, K. (2009). The effect of classroom management skills of elementary school teachers on undesirable discipline behavior of students. Procedia Social and Behavioral Sciences, 1, 1215.

Kerr, M. M., and Nelson, C. M. (2002). Strategies for addressing behavior problems in the classroom (5thed.). Columbus, $\mathrm{OH}$ : Merrill Prentice Hall.

Kunari ,C (2006); Methods of teaching educational Technology, New Delhi.

Kyriacou, C. (1997). Effective Teaching in Schools. (2nd ed.). Cheltenham: Nelson Thornes.

Lightbown, P., and Spada, N. M. (2006). How languages are learned. Oxford University Press, USA.

Locastro, V. (2001). Teaching English to Large Classes, in TESOL Quarterly, 35 (3): 494.

Martella, R., Nelson, R., and Marchand-Martella, N. (2003). Managing disruptive behaviors in the schools: A school wide, classroom, and individualized social learning approach. Boston: Allyn and Bacon.

McCorskey, J. C., and McVetta, R. W. (1990). Classroom seating arrangements: Instructional communication theory versus student preferences. Communication Education, 27, 99-111. 
McGrath, I. (2002), Materials Evaluation and Design for Language Teaching, Edinburgh: Edinburgh University Press.

McManus, M.( 1995). Troublesome behavior in the classroom. Meeting individual needs. London and New York: Routledge.

Mineduc, F. (2013).Ministerio de Educación Chile. Bases curriculares: idioma extranjero inglés. Autor.

Nayak. A.K and Rao V.K. (2008). Classroom Teaching Methods and Practices. New Delhi. APH. Publishing Corporation.

Northcote, R. (2006). Making Mixed Ability Language Classes Really Work - A Report on the 1996 LTANT Conference. Babel Victoria Then Melbourne Journal of Australian Federation of Modern Language Teachers, 31(3).

Pedders, D. (2006). Are small classes better? Understanding relationships between class size, classroom processes and pupils' learning. Oxford Review of Education, 32(2), 224.

Pedersen, F., and Kronborg, L. (2014). Challenging Secondary Teachers to Examine Beliefs and Pedagogy when Teaching Highly Able Students in Mixed-Ability Health Education Classes. Australasian Journal of Gifted Education, 23.

Prodromou, L. (1992). Mixed ability classes. London: MacMillan.

Renaud, S., Tannenbaum E., and Stantial, P. (2008), Student-Centered Teaching in Large Classes with Limited Resources. Retrieved from http://maggiie.blogbus.com/logs/21227901.htm.

Santrock, J.W. (2006). Educational psychology:Classroom update: Preparing for PRAXIS TM and practice. (2nd ed). New York: Mc Graw Hill.

Sarwar, Z. (2001). Adapting Individualization Techniques for Large Classes, in Innovation in English Language Teaching - $A$ Reader (eds David A. Hall\& Ann Hewings), Routledge, 127, 158.

Shawer, S. (2010). The influence of assertive classroom management strategy use on student-teacher pedagogical skills. Academic Leadership, 8(2), 1-11. 
Siebert, C. J. (2005). Promoting preservice teacher's success in classroom management by leveraging a local union's resources: A professional development school initiative. Education, 125, 385-387.

Smith and Lastleth. (2002). Effective Classroom Management: A Teacher's Guide (2nd ed.). New York: Routledge.

Snyder, D. (1998). Classroom Management for Student Teachers. Music Educators Journals, 37-40.

Tomlinson, C. A. (2001). How to differentiate instruction in mixedability classrooms. Alexandria, VA: ASCD.

Tomlinson, C. A., and McTighe, J. (2006). Integrating differentiated instruction \& understanding by design: Connecting content and kids. Alexandria, VA: ASCD.

Trussell, R. P. (2008). Classroom universals to prevent problem behaviors. Intervention in School and Clinic, 43, 179-181.

Wannarka, R., and Ruhl, K. (2008). Seating arrangements that promote positive academic and behavioral outcomes: A review of empirical research. Support for Learning, 23, 89-91.

Watson Todd, R. (2006). Why investigate large classes?. Reflection Journal. Retrieved from:

http://arts.kmutt.ac.th/sola/rEFL/Vo19_Reflections_Large_Clas ses.pdf.

Wood, A. T., and Carol, H. ( 2001) The Case Study Method: Critical Thinking Enhanced by Effective Teacher Questioning Skills. Annual International Conference of the World Association for Case Method Research\& Application, Sweden, June 17-20, 2001.

Wright, T. (2005). How to be a brilliant English teacher. New York: Taylor \& Francis Inc. 


\section{Appendix A}

\begin{tabular}{|l|l|l|}
\hline Statement of problems & Agree & Disagree \\
\hline $\begin{array}{l}\text { 1-The behavior problems can disrupt the } \\
\text { teaching and learning processes. }\end{array}$ & & \\
\hline $\begin{array}{l}\text { 2-To deal with behavior problems have a } \\
\text { dramatic impact on a teacher's job and take } \\
\text { more time. }\end{array}$ & & \\
\hline $\begin{array}{l}\text { 3-My students do not listen to me and they have } \\
\text { lack of attention. }\end{array}$ & & \\
\hline $\begin{array}{l}\text { 4-Large class size affects the quality of my } \\
\text { teaching and influences useful monitoring / } \\
\text { evaluation of lessons }\end{array}$ & & \\
\hline $\begin{array}{l}\text { 5-My students can obtain the same level of } \\
\text { learning in mixed ability class }\end{array}$ & & \\
\hline $\begin{array}{l}\text { 6-It is difficult to plan a lesson that fits all } \\
\text { students with their different abilities }\end{array}$ & & \\
\hline $\begin{array}{l}\text { 7-The course books' activities do not suit the } \\
\text { different levels of my students }\end{array}$ & & \\
\hline $\begin{array}{l}\text { 8-The classroom seating arrangement effects } \\
\text { student to teacher interaction at class }\end{array}$ & & \\
\hline Statements of coping strategies & \\
\hline $\begin{array}{l}\text { 1-Provide clear instruction and positive } \\
\text { feedback to the students for following class rules }\end{array}$ & & \\
\hline 2-Asking questions to get students' attention & & \\
\hline 3-Using group / pair work activities & & \\
\hline $\begin{array}{l}\text { 4-Make use of eye contact, voice control, body } \\
\text { language, and distance management to maintain } \\
\text { large class's control }\end{array}$ & & \\
\hline $\begin{array}{l}\text { 5-Creating a friendly atmosphere while teaching } \\
\text { a big class }\end{array}$ & & \\
\hline $\begin{array}{l}\text { 6-Using lesson plans effectively and the } \\
\text { teaching aids that fits all students with different } \\
\text { abilities }\end{array}$ & & \\
\hline $\begin{array}{l}\text { 7-When students' desks are arranged in rows, } \\
\text { your students tend to stay on-task, focus, listen, } \\
\text { and complete more work }\end{array}$ & & \\
\hline
\end{tabular}

